\title{
Yerel Kalkınmada Üniversite-Kalkınma Ajansı İşbirliği: Türkiye (İzmir) Örneği
}

\author{
Fatih Çelik*
}

Milli Ĕ̆itim Bakanliğı

orcid.org/0000-0002-4486-5722

\section{$\ddot{O} z$}

Bölgesel kalkınma, yerel aktörlerin işbirliğinde mevcut potansiyelin harekete geçirilmesi ve geliştirilmesi şeklinde tanımlanabilir. Yerel aktörlerden başlıcaları, Bölgesel Kalkınma Ajansı ve üniversitelerdir. Bölgesel Kalkınma Ajansı, yerel kalkınmayı hızlandırmak üzere aktörler arasında işbirliğini sağlamak için kurulan bir örgüttür. Yerel aktörlerle birlikte projeler geliştirmekte ve uygulamakta; bu projelere mali ve teknik destek vermektedir. Yerel kalkınmanın aktörlerinden bir diğeri üniversitelerdir. Bir yükseköğretim kurumu olan üniversiteler, mezunları ve Ar-Ge faaliyetleri ile yerel kalkınmaya katkıda bulunmaktadır. Bölgesel Kalkınma Ajansları'nın da desteği ile projeler uygulamaktadır. Çalışmanın amacı, ajanslarm ve üniversitelerin yerel kalkınmaya yönelik işbirliği faaliyetlerini Türkiye (İzmir) örneğinde incelemektir. Araştırma, İzmir Kalkınma Ajansı'nın yerel üniversitelerle stratejiler geliştirme ve projeler gerçekleştirme faaliyetlerinin analizi ile sinırlandırılmıştır. Konu, nitel araştırma yöntemlerinden doküman analizi tekniği ile incelenmiştir. Analiz sonucunda İzmir Kalkınma Ajansı'nın üniversiteler ile işbirliği içinde stratejiler geliştirdiği ve Ar-Ge projelerini desteklediği tespit edilmiştir.

Anahtar Kelimeler: Bölgesel Kalkınma Ajansı (BKA), Üniversite, İşbirliği (Yönetişim), İzmir Kalkınma Ajansı (IZZKA), Üniversite-İZKA İşbirliği.

\section{The Cooperation of University-Development Agency in Local Development: The Case of Turkey (Izmir)}

\begin{abstract}
Regional development can be defined as the mobilization and development of the existing potential in the cooperation of local actors. The main local actors are Regional Development Agency and universities. The Regional Development Agency is an organization established to cooperate with actors to speed up local development. It develops and implements projects with local actors; providing financial and technical support to these projects. Another of the actors of local development is the universities. Universities which are a higher education institution contribute to local development with graduate and RED activities. They are implemented the projects with the support of Regional Development Agencies. The purpose of the study is to examine agencies and university cooperation activities of local development for Turkey (Izmir) example. The research is limited to the analysis of Izmir Development Agency's activities to develop strategies and realization of projects with local universities. The subject was examined by qualitative research methods using document analysis technique. As a result of the analysis it was determined that Izmir Development Agency developed strategies in cooperation with the universities and supports RED projects.
\end{abstract}

Keywords: Regional Development Agency (RDA), Universty, Cooperation (Governance), Izmir Development Agency (IZKA), University-IZKA Cooperation. 


\section{Giriş}

Bölgesel ${ }^{1}$ kalkınma, kısaca yerel aktörlerin işbirliğinde mevcut potansiyelin harekete geçirilmesi ve geliştirilmesi şeklinde tanımlanabilir. Yerel aktörlerden başlıcaları, Bölgesel Kalkınma Ajansı (BKA) ve üniversitelerdir (Goddard ve Chatterton, 1999). BKA'lar, merkezi ve/veya yerel aktörler tarafından kurulmuştur. Başlıca amacı, yerel kalkınmada aktörler arasında işbirliğini (yönetişim) geliştirmektir. Yönetimi, “çok düzeyli yönetişim modeli"ne dayanmıştır (Dulupçu, 2006: 244-245).

Türkiye'de BKA'lar 2, 2006-2009 döneminde kurulmuştur. Bunlardan biri, İzmir' de 2006 yılında kurulan İzmir Kalkınma Ajansı'dır (İZKA).

Yerel aktörlerden bir diğeri, üniversitelerdir. Bir yükseköğretim kurumu olan üniversiteler, eğitim ve Ar-Ge faaliyetleriyle yerel kalkınmaya katkıda bulunmaktadır.

Bu çalışmada, İZKA'nın ve üniversitelerin İzmir'in kalkınmasına yönelik işbirliği faaliyetleri analiz edilmiştir. Çalışma, dört bölümden oluşmuştur. Birinci bölümde, BKA, üniversite, yönetişim yaklaşımı ve Üniversite-BKA İşbirliği (ÜKAİ) kavramları açıklanmıştır. İkinci bölümde, konuya ilişkin literatür özeti verilmiştir. Üçüncü bölümde, araştırmanın amacı, yöntemi, sinırları ve sinırlılığı ortaya konmuştur. Son bölümde ise, öncelikle İzmir ve İZKA hakkında bilgi verilmiştir. Daha sonra Üniversite-İZKA İşbirliği'nde geliştirilen stratejiler ve projeler ele alınmıştır.

\section{Kavramsal Çerçeve}

Bu bölümde, BKA, üniversite, yönetişim yaklaşımı ve ÜKAİ kavramları kısaca açıklanmıştır.

\subsection{Bölgesel Kalkınma Ajansı (BKA)}

Büyük Bunalım'dan (1929) sonra yerel kalkınmadan sorumlu kurumlar olarak BKA'lar kurulmuştur. BKA'lar, yerel kalkınmanın bir katalizörü ve destekleyicisi olarak aktörler arasında işbirliğini sağlamak, içsel ve dışsal kaynaklara dayalı kalkınmayı hızlandırmak için kurulan örgütlerdir (Çelik ve Yıldız, 2015: 533). ABD'de 1930'larda; Avrupa'da, 1950'lerde; Türkiye'de ise, 2000'lerde kurulmaya başlanmıştır.

BKA'ların amacı, ekonomik, çevresel ve sosyal olmak üzere üç grupta ele alınabilir (EURADA, 1999: 25). Başka bir ifadeyle bölgenin kalkınmasını sağlamak, çekiciliğini artırmak, sosyo-kültürel değerlerini korumak ve geliştirmektir.

Merkezi ve/veya yerel aktörler tarafından "çok düzeyli yönetişim modeli"ne göre kurulmuştur (Halkier, 2006: 23-24). Yönetim bakımından ikili bir yapıya sahiptir. Birincisi, Genel Kurul, Yönetim Kurulu, Denetleme Komitesi ve Genel Müdür gibi birimlerdir. İkincisi, çalışma grupları veya komitelerdir (EURADA, 1999: 34-35). Halkier et al., (1998) ile Halkier'e (2000: 42; 2010: 29; 2011) göre örgütlenme bakımından ideal bir BKA, aşağıdan yukarıya doğru yapılanmıştır ve merkezi yönetimden yarı

\footnotetext{
1 Bu çalışmada, bölgesel ve yerel kavramları aynı anlamda kullanılmıştır.

2 Türkiye'de ajanslar, literatürdeki gibi Bölgesel Kalkınma Ajansı yerine siyasi endişelerle Kalkınma Ajansı (KA) şeklinde adlandırılmıştır. Çalışmada, BKA kavramı kullanılmıştır.
} 
özerk, çok işlevli bir kurumdur. Bu yapılanma ve yarı özerklik, BKA'lara aktörler arasında aracılık rolünü vermiştir (Roberts ve Lloyd, 1999: 519-520).

Finansmanı, kamu kaynakları, özel fonlar ve hizmet gelirleri ile sağlanmıştır. Bunlar, ulusal ve bölgesel yönetimlerin aktardığı ödenekler, küresel kurumlardan sağlanan fonlar ve sunulan hizmetlerden elde edilen gelirlerdir (EURADA, 1999: 52).

Başlıca faaliyetleri, bölgesel planlar ve araştırmalar yapmak, veri tabanları oluşturmak, mesleki eğitimi geliştirmek, yenilik ve teknoloji transferi yapmak, yatırımcılara destek olmak ve uluslararasılaşma (EURADA,1999: 65). Yerel kalkınmada yenilikçilik (kümelenme, yenilik ve ağ) faaliyetlerini yürütmüştür (Çelik, 2015: 40). Bölgesel Yenilik Sistemi'nin (BYS ${ }^{3}$ ) aracı kurumu olarak şu araçları kullanmıştır: Danışmanlık, mali destek, teknoloji transferi, beşeri sermaye yatırımı, kümeler ve ağlar kurulması (Tödtling, 2001: 3-4). Teknopark ${ }^{4}$ gibi kurumlar kurarak; firmalara, rekabet öncesi hizmetler ("reel hizmetler") vermiştir. BYS'nin temel bir unsuru olan Reel Hizmet Merkezleri (RSCs), teknopark, yenilik merkezi gibi isimlerle adlandırılmıştır (Bellini, 2000: 711-712; Clara, 2000: 4).

\section{2. Üniversite}

Bir yükseköğretim kurumu olan üniversiteler, aktörler arasında işbirliğini sağlayarak yerel kalkınmaya katkıda bulunmaktadır (Porter, 2007: 43). Dolayısıyla üniversiteler de "bölgesel kalkınmanın başlıca aktörlerinden biri"dir (Charles, 2006: 117; Wolfe, 2005: 1; Trippl et al., 2014: 4).

Üniversiteler, zamanla önemli yapısal ve fonksiyonel değişikliklere ${ }^{5}$ uğramıştır. Başlangıçta yükseköğretim; 19. yüzyıldan itibaren araştırma yapma; 20. yüzyılın ortalarından sonra da Ar-Ge gibi yeni roller üstlenmiştir (Etzkowitz ve Leydesdorff, 1995: 14-15; Youtie ve Shapira, 2008: 1189; Albulescu ve Albulescu, 2014: 5-6). Bir firma gibi ekonomik yararlılık anlayışını benimseyen üniversiteler, küreselleşme ile piyasaya uyumlu Ar-Ge yaparak "bilgi fabrikası"na dönüşmüştür (Bramwell ve Wolfe, 2005: 2). Böylece "girişimci üniversite" 6 ve "şirket üniversitesi" gibi yeni üniversite modelleri ortaya çıkmıştır. Girişimci üniversite, araştırma ve öğretim ile bilgi transferi ("üçüncü misyon”) rollerini üstlenmiştir (Etzkowitz ve Leydesdorff, 2000: 110). Bazı firmalar ise, üniversiteden bekledikleri işlevleri üniversite (şirket üniversitesi) kurarak gerçekleştirmiştir.

\footnotetext{
${ }^{3}$ BYS kısaca, bilginin üretildiği, kullanıldığı, yayıldığı ve aktörlerin etkileşim içinde olduğu bir ortamdır.

4 Teknopark, üniversite veya araştırma kurumunun öncülüğünde üretilen bilginin ticarileştirilmesini amaçlayan; bünyesinde, Ar-Ge ve yenilik temelli firmalar olan kurumdur (Asheim ve Isaksen, 1996: 42).

${ }^{5}$ Wissema (2009: 3, 23) üniversiteleri, 900 yıllık tarihlerinde üstlendikleri rollere göre üç dönemde gruplandırmıştır. Bunlar, 1. Kuşak Üniversiteler (1GU; bilim odaklı ortaçağ üniversiteleri), 2. Kuşak Üniversiteler (2GU; Humboldt modeli, eğitim ve araştırma odaklı üniversiteler) ve 3. Kuşak Üniversiteler (3GU; girişimci ve toplumla bütünleşen üniversiteler).

${ }^{6}$ Clark (1998), Avrupa'daki beş üniversiteyi inceleyerek girişimci üniversite kavramını geliştirmiştir. 19. yüzyılda ilk araştırma üniversitesi olarak Almanya'da kurulan Berlin Üniversitesi (1810), girişimci üniversitelere öncülük etmiştir. Etzkowitz (2003: 110), araştırmacı üniversitelerin kurulmasını I. Akademik Devrim; girimci üniversitelerin ortaya çıkmasını, II. Akademik Devrim; Etzkowitz ve Viale (2010) de üçlü sarmal modelinin girişimci üniversiteleri içermesini, III. Akademik Devrim olarak adlandırmıştır.
} 
Günümüzde üniversiteler, eğitim ve araştırmanın yanısıra ekonomik ve sosyal gelişmeye katkıları ile katalizör olarak görülmüştür. Yapılan çalışmalarda da üniversitelerin yerel kalkınmanın "motor" $u$ olarak kilit rolleri vurgulanmıştır (Popescu, 2011: 1-2). Üniversitelerin yerel kalkınmaya katkıları, ekonomik kurum ve bilgi üreticisi ile beşeri sermaye yetiştiricisi ve ağlar kurucusu ve yöneticisi rolleri ile incelenmiştir. Bunlardan ilk ikisi, ekonomik; diğerleri ise, sosyo-kültürel unsurlara yoğunlaşmıştır. Ekonomik kurum olarak üniversitelerin rolü, ücret ödeyen bir işveren ve harcama yapan öğrencileri çeken bir kurumdur. İkinci rolü, fikri mülkiyet hakları, teknoloji transferi, teknoparklar ve spin-off 7 firmalar aracılığıyla bilginin ticarileştirilmesidir. Üçüncüsü, bölge ekonomisine nitelikli işgücü yetiştiren bir eğitim kurumudur. Dördüncü rolü ise, kurduğu ve yönettiği öğrenme, yenilik ve yönetişim ağları aracılığıyla aktörlerle etkileşimi ile ilgilidir (Boucher et al., 2003: 888-889).

Üniversitelerin yerel kalkınmadaki rolleri, çeşitli yaklaşımlarla ele alınmıştır. Bunlardan biri, Etzkowitz ve Leydesdorff'un (1995: 15) geliştirdiği Üçlü Sarmal Modeli'dir. Girişimci üniversiteleri önemli bir aktör olarak kabul eden bu model, üniversite-sanayi-devlet işbirliğine dayanmıştır. Modele göre üniversite, teknoparklar ile firma kurucu; sanayi, üniversiteler için uygulamalı eğitici; devlet ise, finansman sağlayan bir rol üstlenmiştir. Devlet, aktörler arasında aracılık da yapmıştır. Bu konuda bir diğer aktör, kamu kurumu olan BKA'lardır (Trippl et al., 2012: 9, 13, 19). Yerel kalkınmaya katkıları nedeniyle üniversite kurmak, BKA'ların kalkınma stratejilerinde yer alan bir unsur olmuştur (Harloe ve Perry, 2004: 212, 2016).

\subsection{Yönetişim Yaklaşımı}

1980'li yıllarda başlayan küreselleşme sürecinin etkilerinden biri, ülkeleri yönetimden yönetişime geçişe zorlamasıdır. Küresel sermayenin aktörleri olan ulusüstü kurumlar $^{8}$, ülkelere ticari serbestleşme, ademi merkezileşme ve yönetişim modelinin benimsetilmesi konusunda hemfikir olmuşlar (Müftüoğlu, 2012: 98).

Yönetişim kısaca, kamu, özel ve sivil kesim aktörlerinin işbirliği yapmasıdır. Yönetişim modelinde herhangi bir aktör, karar verme sürecine egemen değildir (Dulupçu, 2006: 244-245). BKA'ların yönetiminde, yönetişim modeli esas alınmıştır. Bu model, iki temel özelliğe sahiptir. İlki, katılımcllıktır. Yani yetki ve sorumlulukların kamu, özel ve sivil aktörler arasında paylaşılmasıdır. İkincisi ise, hiyerarşik yapıdan eşitler arası ilişkilere dayalı bir heterarşik yapının kurulmasıdır (Eraydın, 2007: 11-12).

Yönetişim modelinde, Marks ve Hooghe'ın (2004) geliştirdiği tipoloji temel alınmıştır. Yazarlar, modeli iki şekilde gruplandırmıştır. Bunlar, Tip 1 ve Tip 2 yönetişim modeli. Tip 1'de yetki dağılımı, coğrafi olarak sınırlıdır. Tip 2'de ise, mekan ve aktörler bakımından bir yetki sınırlaması yoktur. Yönetişim, tüm aktörlerin katılımı ile çok düzeyli bir şekilde gerçekleştirilir (Helvacıoğlu ve Tektaş, 2010: 530-531).

\footnotetext{
7 Spin-off, teknoloji yoğun firmalarda veya üniversitelerde Ar-Ge faaliyetleri ile geliştirilen ürünler/ sistemler için alınan lisansı/patenti ticarileştirmek üzere kurulan firmalardır.

${ }^{8}$ Uluslararası Para Fonu, Dünya Bankası, Dünya Ticaret Örgütü, Ekonomik Kalkınma ve İşbirliği Örgütü.
} 


\section{4. Üniversite-Bölgesel Kalkınma Ajansı İşbirliği (ÜKAİ)}

ÜKAİ kavramı, kısaca üniversitelerin ve BKA'ların yönetişim yaklaşımı temelinde yerel kalkınmaya yönelik işbirliği faaliyetleri şeklinde tanımlanabilir. Üniversite-Sanayi İşbirliği'nden (ÜSİं) esinlenilerek Çelik ve Yıldız (2015) tarafından geliştirilmiştir. BKA'lar, ekonomik kalkınmayı sağlamak üzere başta üniversiteler yerel aktörlerle işbirliği içinde bölgenin Ar-Ge ve yenilik yapma kapasitesini artırmak için küme ve teknopark gibi yapıların kurulmasına öncülük etmiştir (Salvador, 2008: 15).

ÜKAİ, İngiltere, İrlanda, Avusturya ve Türkiye örneğinde ele alınabilir. İngiltere' de ${ }^{10}$ Kuzey Batı Kalkınma Ajansı (NWDA), İmalat Mükemmellik Merkezi'ni, Joule Merkezi'ni ve Kompozitler Merkezi'ni kurmuş; Mersey Waterfront Bölge Parkı'nı 19,8 milyon $£$, Biomedikal Araştırma Merkezi'ni 9,5 milyon $£$, MedyaKentiUK'yı 45 milyon $£$ tutarında desteklemiştir. Cumbria Üniversitesi'nin kurulmasına öncülük etmiştir (Morris, 2010: 21; NWDA, 2011a: 24-25). Ulusal Nükleer Beceri Akademisi'ne 6 milyon $£$; 34 milyon $£$ ile kurduğu Ulusal Biyoimalat Merkezi'nde yeni ilaçlar geliştirilmesi için de 30 milyon $£$ vermiştir (TSB, 2010: 15, 27). Tropikal ve Enfeksiyon Hastalıkları Merkezi'ni 23 milyon £; Daresbury Laboratuvarı, Daresbury Yenilik Merkezi ve Cockcroft Enstitüsü'nden oluşan Daresbury Bilim ve Yenilik Kampüsü'nü 50 milyon $£$ tutarında desteklemiştir (NWDA, 2011b: 4-5).

İrlanda'nın Shannon Bölgesi'nin kalkınmasını yönlendiren başlıca iki kurum, Shannon Kalkınma Ajansı (SD, 1959) ve Ulusal Teknoloji Parkı'dır (NTP, 1984). SD, yerel ekonominin nitelikli işgücü ihtiyacı üzerine Limerick Üniversitesi'nin (UL, 1972) kurulmasına öncülük etmiştir. SD-UL işbirliğinde kurulan ve yönetilen NTP, ülkenin ilk teknoparkıdır. NTP, UL'nin eğitim ve Ar-Ge imkanlarını firmalara sunmuştur. SD tarafından NTP bünyesinde kurulan Yenilik Merkezi, kuluçka hizmeti vermiştir (Roper et al., 2002: 8). SD, NTP deneyimi ile Kerry Teknoloji Parkı, Tipperary Teknoloji Park1, Ennis Bilgi Çağı Parkı ve Birr Teknoloji Merkezi'ni; bunları birbirine bağlayarak da "bilgi ağı"nı (SDKN, 2001) kurmuştur (OECD: 14-15, 18: Çelik, 2018b: 27). Bu gelişme süreci, "öğrenen bölge" nin ortaya çıkışı ile karekterize edilmiştir (Boucher, 2000: 4).

Avusturya'nın Styria Bölgesi'nin kalkınma ajansı SFG'dir. SFG'nin kurduğu otomotiv kümesi AC Styria, firmaların Ar-Ge ve yenilik faaliyetlerini desteklemek için Graz Teknik Üniversitesi, Joanneum Araştırma Enstitüsü ve Leoben Üniversitesi ile işbirliği yapmıştır. SFG'nin finanse ettiği Styria Teknoloji Parkı, Graz Bilim Parkı, Grambach Teknoloji ve Pazarlama Merkezi, Niklasdorf Teknoloji ve Eğitim Merkezi ve Kapfenberg Teknoloji Merkezi'nden oluşmuştur. SFG'nin öncülüğünde kurulan Yukarı Styria İş Parkı ise, Ar-Ge kurumlarını içeren bir ağdır (Tödtling et al., 1998: 35-37). SFG,

\footnotetext{
9 Tarihsel kökeni 1850'li yıllara dayanan ÜSİ, üniversitenin Ar-Ge altyapısı ve beşeri sermayesi ile sanayi sektörünün kaynaklarını (deneyim, finansman vb.) bir araya getirmek için kurulan karşılıklı etkileşim ortamidır (Dura, 1994: 101). Dünya Ekonomik Forumu'nun 2014-2015 Küresel Rekabetçilik Raporu'na göre, ÜSİ konusunda 144 ülke arasında ilk beşte olan ülkelerden bazıları, rekabet edebilirlikte de ilk beşte yer almıştır. Buna göre, küresel rekabet ve ÜSİ arasında bir ilişki olduğu söylenebilir (TCBSTB, 2015: 5-6). 10 İngiltere' de BKA'lar, çeşitli nedenlerle 2012 yılında kapatılmıştır (Çelik, 2017c: 148).
} 
yeni teknolojiye dayalı firmalarının kurulması için de Graz Bilim Parkı'na ve Leoben Uygulamalı Teknoloji Merkezi'ne mali destek vermiştir (Holzschlag et al., 2009: 20).

Türkiye'de de BKA'lar, teknopark kurmaya yönelik projelere destek vermiştir. Bu kapsamda Karaman İş Geliştirme Merkezi (2011), Konya Bölgesel İnovasyon Merkezi (2011), Çorum Teknoloji Geliştirme Bölgesi (2012), İzmir İnovasyon Merkezi (2012) gibi yapıların kurulmasını desteklemiştir (KB, 2012: 78-80; KB, 2013: 86-87).

Kısaca BKA'lar, başta üniversiteler yerel aktörlerle işbirliği içinde bölgenin ArGe ve yenilik yapma kapasitesini geliştirmek için teknopark gibi kurumlar; bunları birbirine bağlamak suretiyle de BYS kurmuşlar. Yenilikler, çok düzeyli işbirliğini gerektirmiştir (Cooke, 2004: 513; Uyarra ve Haarich, 2002: 2). Bu bakımdan BYS, iki alt sistemden oluşmuştur. Bunlar, bilgi üretme ve yayma alt sistemi (bilginin üretilmesi ve yaygınlaştırılması ile uğraşan kurumlar) ile bilgiyi uygulama ve kullanma alt sistemi (firmalar, müşteriler, tedarikçiler, rakipler, ortaklar) (Tödtling ve Trippl, 2005: 1205; Camagni ve Capello, 2012: 8). Cooke'a (2001) göre, bu iki alt sistemin etkileşimi ile BYS ortaya çıkar (Uyarra, 2008: 12).

$A B$, yenilik sürecinde arz ve talep tarafının (iki alt sistemin) etkileşimini sağlamıştır (Landabaso ve Reid, 1999: 18). Kimi aktörlere de bu konuda aracı rolünü vermiştir. Buna göre BYS'nin, Şema 1'de sunulduğu gibi başlıca üç aktörden oluştuğu söylenebilir (Cooke ve Memedoviç, 2003: 10).

Şema 1: BYS'nin Tarafları

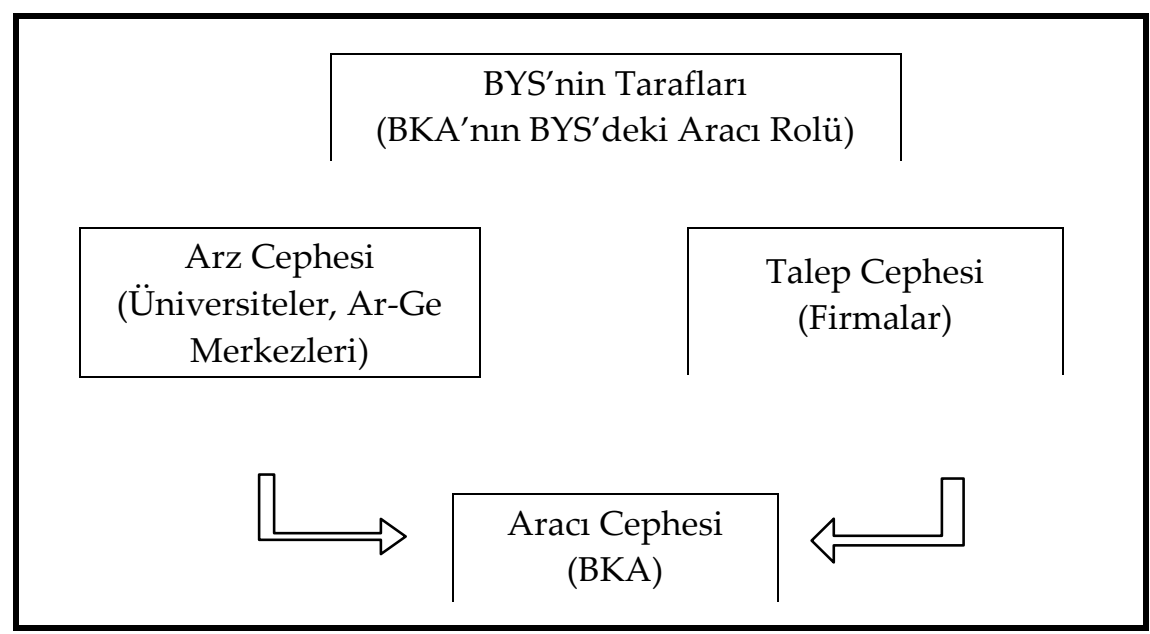

Kaynak: Çelik, 2015: 193.

Şema 1'e göre. BYS'nin arz tarafında, bilgi üreten üniversiteler ve Ar-Ge merkezleri; talep tarafında, bilgiyi kullanan firmalar; aracı tarafında ise, bunları bir araya getiren kurumlar yer almıştır (Sungur ve Keskin, 2011: 163). BKA'lar, BYS'nin arz ve talep cephesini bir araya getiren aracı taraf rolünü üstlenmiş; bu iki tarafın yeniliklere yönelik işbirliği yapmasını sağlamıştır. BKA'ların bu aracı rolü temelinde yeni bir işbirliğinin, Üniversite-BKA İşbirliğgi'nin (ÜKAİ) ortaya çıtı̆̆g gözlenmiştir. 


\section{Literatür Özeti}

Literatürde ÜSİ, çok sayıda araştırmaya konu olurken; ÜKAİ́yi ele alan bir çalışma (Çelik ve Yıldız, 2015) olduğu anlaşılmıştır. Bu konuda kısmen, Dineen (1995), Boucher (2000), Parker (2008), Eren ve Koşan'ın (2012) çalışmalarından söz edilebilir.

Dineen (1995), İrlanda'da Shannon Kalkınma Ajansı'nın (SD, 1959) öncülüğünde kurulan Limerick Üniversitesi'nin (UL, 1972) yerel kalkınmaya katkısını doküman analizi tekniği ile incelemiştir. Geliştirdiği yerel kalkınma stratejisinde, UL'nin mezunları ve Ar-Ge altyapısı ile yerel kalkınmada önemli bir kaynak olduğunu, bölgede teknolojinin ve beşeri sermayenin gelişmesine katk1 sağlayabileceğini belirterek; UL'yi, Limerick Modeli olarak nitelendirmiştir.

Boucher (2000) de UL'nin yerel kalkınmadaki rolünü vaka analizi tekniği ile ele almıştır. UL'nin, yerel kalkınmaya katkıları ile literatürde UL Modeli olarak yer aldığını; SD’nin de bu model temelinde Tralee Teknoloji Enstitüsü'nü, Kerry Teknoloji Parkı'nı ve Tipperary Kırsal ve İş Geliştirme Enstitüsü'nü kurduğunu tespit etmiştir.

Parker (2008), bilişim sektöründeki girişimlerin yönetişimini, Limerick (İrlanda), Karskrona (İsveç) ve Adelaide (Avustralya) örneklerinde mülakat tekniği ile incelemiştir. Analizle SD'nin, Limerick'de girişimcilik faaliyetlerinin gelişmesinde önemli rol oynadığını belirlemiştir. SD'nin yönetişim temelinde UL'nin (1972), UL bünyesinde Yenilik Merkezi'nin (IC, 1980) ve Ulusal Teknoloji Parkı'nın (NTP, 1984) kuruluş sürecindeki rolünü örnek göstermiştir. Bu bakımdan SD'nin, başlangıçta Shannon Havaalanı gibi "hard" altyapıya; daha sonra da bilişim sektöründeki girişimleri desteklemek için "soft" (bilgi) altyapıya odaklandığını belirlemiştir.

Eren ve Koşan (2012), konuyu daha ziyade “teorik” olarak ele almışlar. BKA'lar, üniversiteler ve girişimciler arasındaki işbirliğini inceleyerek, Türkiye'de verimliliği artırma yollarını araştırmışlar. Verimliliği ve bölgesel kalkınma düzeyini artırmak için BKA-üniversite işbirliğini önermişler.

Çelik ve Yıldız (2015), yerel kalkınmada SD-UL işbirliğinden (SD-UL Modeli ${ }^{11}$ ) hareketle ÜKAİ kavramını geliştirmişler. Bu işbirliği ile kurulan/geliştirilen Shannon Serbest Bölgesi, Ulusal Teknoloji Parkı, Shannon Yazılım ve Shannon Tedarik Ağı'nı inceleyerek; UL'nin yerel kalkınmada yeniliklerin öncüsü olduğuna kanaat getirmişler.

\section{Araştırmanın Amacı, Yöntemi, Sınırları ve Sınırlılığı}

BKA'lar, yönetişime dayalı bir örgüt olarak kabul edilir. Başlıca görevlerinden biri, yerel aktörleri ortak bir amaç için bir platformda buluşturmak ve yaratılan sinerji ile bölgesel kalkınmayı hızlandırmaktır. Yerel aktörlerden biri olan üniversiteler ile işbirliği (ÜKAİ) faaliyetleri, yerel kalkınma için oldukça önemlidir.

Yönetişim yaklaşımı, AB’ye göre 5 ilkeye dayanmaktadır. Bunlar, açıklık, katılımcilık, hesap verebilirlik, etkinlik ve uyum'dur (CEC, 2001: 10). Karar alma, uygulama ve denetleme gibi boyutları içeren katılımcılık, kamu gücünün kötüye

\footnotetext{
${ }^{11}$ Yerel kalkınmada SD ve UL işbirliği, literatüre SD-UL Modeli olarak geçmiştir.
} 
kullanılmasını önlemek, kamusal düzenlemelere uyumu artırmak, paydaşlar arasında uzlaşma sağlamak gibi yönlerden önemlidir (Güney ve Sat, 2016: 103-104).

Bu araştırmanın amacı, İzmir' de katılımcılık temelinde İZKA'nın üniversitelerle işbirliği içinde uyguladığı projeleri, Tablo 1'de sunulan kriterlere göre analiz etmektir.

Tablo 1. Üniversite-BKA İşbirliği'ni (ÜKAİ) Değerlendirme Kriterleri

\begin{tabular}{|c|}
\hline Kriter \\
\hline - Üniversite-BKA İşbirliği yapılan üniversite sayısı \\
\hline • Üniversite-BKA İşbirliği'nde uygulanan proje sayısı \\
\hline • Üniversite-BKA İşbirliği'nde uygulanan projelerin bütçesi (BKA'nın katkısı) \\
\hline
\end{tabular}

Kaynak: Yazar tarafından geliştirilmiştir.

Tablo 1'e göre ÜKAİ, işbirliği yapılan yerel üniversite sayısına, uygulanan proje sayısına ve projelere verilen destek miktarına göre incelenebilir.

Çalışma, İZKA'nın İzmir'deki üniversiteler ile strateji geliştirme ve proje gerçekleştirme temelinde işbirliği faaliyetlerinin analizi ile sınırlandırılmıştır. Analiz konusu olarak İzmir' in ve İZKA'nın seçilmesinin başlıca nedenleri şunlardır:

- İzmir, Ege Ekonomiyi Geliştirme Vakfı (EGEV ${ }^{12}$, 1992), Ege Bölgesi Kalkınma Ajansı $\left(\right.$ EBKA $\left.^{13}, 1993\right)$, Başkanlar Kurulu ${ }^{14}$, İzmir İçin Yeni Sinerjiler Enstitüsü ${ }^{15}$ (2004), İzmir Ekonomik Kalkınma ve Koordinasyon Kurulu (İEKKK ${ }^{16}$, 2009) ve IZKKA ${ }^{17}$ gibi Türkiye' de model olabilecek yönetişim yapılarına sahiptir.

- İzmir, Türkiye'de ÜSİ'yi (1983) kurumsal olarak başlatan kenttir.

- İzmir, Türkiye'deki 182 üniversiteden 8'ini barındırmakta olup; üniversite sayısına göre ülkenin üçüncü büyük kentidir.

- İzmir'de yerel aktörlerin en fazla (\% 60) işbirliği yaptığı kurum, üniversitelerdir. İkinci sırada ise, İZKA (\% 55) yer almıştır.

- Kısaca İzmir, yerel kalkınmada Üniversite-BKA İşbirliği'ni sağlayacak ve geliştirecek kurumsal ve yönetişim yapılarına sahiptir.

\footnotetext{
12 EGEV, İzmir'de yerel aktörlerin katılımıyla bölgeyi dış yatırımcılara tanıtmak amacıyla 1992 yılında kurulmuştur. 1998 yılında İzmir'in yanısıra 9 kentin katılımıyla tüm Ege bölgesini kapsamıştır. EGEV'in yerel kalkınma girişimleri, İzmir'de güçlü bir yönetişim yapısının olduğunu göstermiştir.

${ }^{13}$ İzmir'in BKA konusundaki ilk deneyimi, İzmir Ticaret Odası'nın ve AB'nin işbirliğinde 1993 yılında kurulan EBKA'dır. Türkiye'nin ilk bölgesel kalkınma ajansıdır. Misyonu, ortak akıl ve katılımcılık ile bölgeye özgü kalkınma modeli geliştirmektir. 1995 yılında EGEV'in bünyesinde A.Ş’ye dönüştürülmüştür. ${ }^{14}$ Kurulun bazı üyeleri şunlardır: İZTO Başkanı, EBSO Başkanı, İzmir Borsası Başkanı, İzmir İhracatçılar Birliği Başkanı, İzmir Ziraat Odası Başkanı, EGEV Başkanı, Batı Anadolu Sanayici ve İşadamları Derneği. ${ }^{15} 2004$ yılında kurulan İzmir İçin Yeni Sinerjiler Enstitüsü ("İzmir Enstitüsü"), tüzel kişiliği olmayan bir fikir platformudur. İzmir'in yanısıra Türkiye'nin sosyo-ekonomik sorunlarına yönelik projeler geliştirmekte ve bunları ilgili kurumlarla paylaşmaktadır. Yaz ayları hariç her ay toplanmaktadır.

${ }^{16}$ İzmir Büyükşehir Belediyesi'nin (İBB) öncülüğünde 2009 yılında kurulan İEKKK, kentin ekonomisinde belirleyici role sahip 81 tane kurum ve kuruluşun temsilcisinden oluşmuştur.

${ }_{17}$ Türkiye'deki iki pilot BKA'dan biri olan IZKA, İzmir'in, “ortak aktör" kavramının temelini oluşturan sosyal sermayeye sahip bir kent olduğunu göstermiştir. IZKA, yönetişime dayalı örgütsel yapısı ve yerel kalkınma faaliyetleri ile İzmir'de yönetişim yapılarının kurumsallaşmasına katkıda bulunmuştur.
} 
Konu, nitel araştırma yöntemlerinden doküman analizi tekniği ile yapılmıştır. Doküman analizi, konuya ilişkin yazılı materyallerin incelenmesidir. Beş aşamada yapılabilir. Bunlar, dokümanlara ulaşma, orjinalliğini kontrol etme, dokümanları anlama, verileri analiz etme ve kullanma (Yıldırım ve Şimşek, 2013: 217-218, 223).

Çalışmanın başlıca sınırlılığı, Üniversite-İZKA İşbirliği'ne ilişkin verilerin kısıtlı olmasıdır. Bu sınırlılık, kurumsal raporlardan ve bilimsel çalışmalardan derlenebilen verilerle aşılmaya çalışılmıştır.

\section{5. İzmir}

İzmir, yaklaşık 4,3 milyon nüfusa sahip olup; Ege Bölgesi'nin en büyük ve en gelişmiş kentidir. Sosyo-ekonomik gelişmişlik bakımından İstanbul ve Ankara'dan sonra 3. sırada yer almıştır (İZKA, 2010: 20). Türkiye'nin önemli bir diş ticaret merkezidir. Kentte tekstil, mobilya, makine ve teçhizat, metal ve tarım sektörleri öne çıkmıştır. Yenilenebilir enerji, turizm ve lojistik sektörlerinde de önemli potansiyele sahiptir. 2 tane Serbest Bölge (SB) ve 17 tane Organize Sanayi Bölgesi (OSB) vardır. Ülkenin en fazla OSB'ye sahip kentidir (IZKA, 2010: 20-23).

İzmir'de yerel aktörlerin \% 95'inin, Ar-Ge ve yenilik desteklerinden yeterince yararlanmadığı; dolayısıyla bir "rehber"e (BKA) ihtiyaç duyulduğu belirlenmiştir (İZKA, 2012c: 50). Türkiye'nin ilk kalkınma ajansı olan Ege Bölgesi Kalkınma Ajansı (1993) deneyiminin de etkisiyle 2006 yılında İZKA kurulmuştur.

Çalışmanın bu kesiminde öncelikle İzmir'deki üniversiteler; daha sonra İZKA ve onun üniversiteler ile işbirliği faaliyetleri ortaya konmuştur.

\section{1. İzmir' deki Üniversiteler}

Türkiye'deki 186 üniversiteden 8'i İzmir'dedir ${ }^{18}$. Kentin ilk üniversitesi, 1955 yılında kurulan Ege Üniversitesi'dir (EÜ). Daha sonra Dokuz Eylül Üniversitesi (DEÜ, 1982), İzmir Yüksek Teknoloji Enstitüsü (İYTE, 1992), İzmir Ekonomi Üniversitesi (İEÜ, 2001), Yaşar Üniversitesi (YÜ, 2001), İzmir Katip Çelebi Üniversitesi (İKÇÜ, 2010), İzmir Bakırçay Üniversitesi (İBÜ, 2016) ve İzmir Demokrasi Üniversitesi (İDÜ, 2016) kurulmuştur.

İzmir, üniversite sayısına göre Türkiye'nin üçüncü büyük kentidir. Üniversitelerde yaklaşık 9 bin öğretim üyesi, 172 bin öğrenci, 142 araştırma merkezi bulunmakta; her yıl yaklaşık 21 bin öğrenci mezun olmaktadır ${ }^{19}$. Bu veriler, İzmir'in ÜSİ için gerekli beşeri sermaye ve Ar-Ge altyapısına sahip olduğunu göstermiştir.

İzmir'de yerel aktörlerin üniversitelerle işbirliği, yüksek; proje işbirliği ise, düşük bir oranda gerçekleşmiştir. En fazla (\% 60) işbirliği yapılan kurum, üniversitelerdir (özellikle EÜ, DEÜ ve İYTE). Üniversiteleri, İZKA (\% 55), KOSGEB (\% 30) ve TÜBİTAK (\% 25) izlemiştir (İZKA, 2012c: 17).

\footnotetext{
${ }^{18} \mathrm{Bu}$ veriler, http://www.yok.gov.tr/web/guest/universitelerimiz'den derlenmiştir (Erişim Tarihi: 3.5.2018).

${ }^{19} \mathrm{Bu}$ veriler, https://istatistik.yok.gov.tr/'den derlenmiştir (Erişim Tarihi: 3.5.2018).
} 
İzmir'de ÜSİ'nin istenilen düzeyde olmadığı belirlenmiştir. Bunun en somut göstergesi, firmaların "açık yenilik modeli"nden (yalnızca \% 7'si) ziyade "kapalı yenilik modeli" $\mathrm{ni}^{20}$ uygulamasıdır. Bir diğer kanıt, firmalardan yalnızca \% 19'unun ArGe ve yenilik projesi kapsamında ÜSİ yapmasıdır (İZKA, 2012c: 17, 62).

Kısaca İzmir, yenilikçi bölge olmak için gerekli potansiyele sahiptir. Ancak bunu harekete geçirmek için aktörler arasında işbirliğini sağlayacak kurumlara ihtiyaç duyulmuştur. Bu kurumlardan başlıcası, İZKA'dır.

\section{2. İzmir Kalkınma Ajansı (İZKA)}

İZKA, Türkiye'de iki pilot BKA'dan biri olarak 2006 yılında kurulmuştur. Vizyonu, Yenilikçi İzmir'dir. Başlıca amaçları ise şunlardır (IZZKA, 2012b: 18):

- Yerel aktörler arasında işbirliğini geliştirmek,

- Bölgenin rekabet gücünü artırmak,

- Bölgenin sürdürülebilir kalkınmasını sağlamak.

Kalkınma Kurulu, Yönetim Kurulu, Genel Sekreterlik ve Yatırım Destek Ofisi şeklinde örgütlenmiştir. Başlıca gelirleri, kamu ve özel kaynaklardır. Kamu kaynakları, merkezi ve yerel yönetimlerin verdiği ödeneklerdir. Özel kaynaklar ise, sanayi ve ticaret odalarının katkılarıdır.

İZKA, kümelenme yaklaşımı temelinde İzmir'in kalkınmasına yönelik yenilikçilik faaliyetlerinde bulunmuştur (Çelik, 2015: 119). Yerel aktörlerin işbirliği yapma kapasitesini artırmak için TCI Network, INSME, EURADA gibi küresel ağlara üye olmuştur (IZZKA, 2012b: 33, 35). Ayrıca EÜ ile işbirliği yaparak İzmir Kümelenme ve Yenilik Portalı'nı (www.izmirkumelenme.org) kurmuştur.

İKA'ya ilişkin başlıca araştırmalar, konularına göre planlama ve kümelenme faaliyetleri ile etki analizi ve diğerleri şeklinde tasnif edilerek Tablo 2' de sunulmuştur.

\footnotetext{
${ }^{20}$ Firmalar, ÜSI'nin gelişmesiyle kapalı yenilik modelinin yerine açık yenilik modelini uygulamaya başlamıştır. Kapalı yenilik modeli, Ar-Ge ve yenilik faaliyetlerinin yalnızca kurum içi bilgi birikimi ve altyapı ile yapıldığı bir modeldir. Açık yenilik modeli ise, bu faaliyetlerin kurum dışı paydaşlarla işbirliği içinde yapıldığı bir modeldir (IZZKA, 2012c: 11).
} 
Tablo 2. İZKA'ya İlişkin Literatür Özeti

\begin{tabular}{|c|c|c|c|c|}
\hline Konu & Yazar1 & Amac1 & Yöntemi* & Sonucu \\
\hline \multirow{4}{*}{ 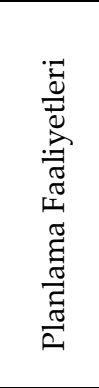 } & $\begin{array}{l}\text { Aydoğdu } \\
(2010)\end{array}$ & $\begin{array}{l}\text { 2009-2013 Bölgesel Gelişme } \\
\text { Planı'nı incelemektir. }\end{array}$ & Anket & $\begin{array}{l}\text { Planlama faaliyetlerinin etkinliği, } \\
\text { yerel aktörlerin katılımı ile artar. }\end{array}$ \\
\hline & $\begin{array}{c}\text { Akpinar } \\
(2010)\end{array}$ & $\begin{array}{l}\text { 2010-2013 Bölge Planı'nı } \\
\text { incelemektir. }\end{array}$ & $\begin{array}{c}\text { Doküman } \\
\text { Analizi }\end{array}$ & $\begin{array}{l}\text { Plan, yönetişim modeline göre } \\
\text { hazırlanmıştır. }\end{array}$ \\
\hline & Burak (2011) & $\begin{array}{l}\text { 2010-2013 Bölge Planı'nı } \\
\text { incelemektir. }\end{array}$ & $\begin{array}{c}\text { Doküman } \\
\text { Analizi }\end{array}$ & $\begin{array}{l}\text { BKA'lar, planlama sürecinde veri } \\
\text { toplayan bir aktördür. }\end{array}$ \\
\hline & $\begin{array}{l}\text { Eldeniz } \\
(2011)\end{array}$ & $\begin{array}{l}\text { İKA'nın performansını, } \\
\text { 2010-2013 Bölge Planı'na } \\
\text { göre belirlemektir. }\end{array}$ & $\begin{array}{c}\text { Mülakat, } \\
\text { Doküman } \\
\text { Analizi } \\
\end{array}$ & $\begin{array}{l}\text { IZKA, planın koordinatörü, } \\
\text { destekleyicisi ve katalizörüdür. }\end{array}$ \\
\hline \multirow{3}{*}{ 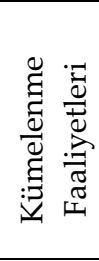 } & $\begin{array}{l}\text { Özdemir ve } \\
\text { İneler (2009) }\end{array}$ & $\begin{array}{l}\text { İKA'nın kümelenme } \\
\text { faaliyetlerini incelemektir. }\end{array}$ & $\begin{array}{c}\text { Doküman } \\
\text { Analizi } \\
\end{array}$ & $\begin{array}{l}\text { İZKA'nın kümelenme faaliyetleri } \\
\text { örnek alınabilir. }\end{array}$ \\
\hline & $\begin{array}{c}\text { Haşar ve } \\
\text { İneler (2011) }\end{array}$ & $\begin{array}{l}\text { İKA'nın kümelenme } \\
\text { faaliyetlerini incelemektir. }\end{array}$ & $\begin{array}{c}\text { Doküman } \\
\text { Analizi }\end{array}$ & $\begin{array}{l}\text { İZKA'nın kümelenme faaliyetleri } \\
\text { örnek alınabilir. }\end{array}$ \\
\hline & $\begin{array}{l}\text { Günaydın } \\
(2013 a)\end{array}$ & $\begin{array}{l}\text { İKA'nın kümelenme } \\
\text { faaliyetlerini incelemektir. }\end{array}$ & $\begin{array}{c}\text { Doküman } \\
\text { Analizi } \\
\end{array}$ & $\begin{array}{l}\text { IZKA'nın kümelenme faaliyetleri } \\
\text { örnek alınabilir. }\end{array}$ \\
\hline \multirow{4}{*}{ 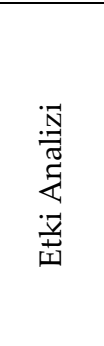 } & İZKA (2011) & $\begin{array}{l}\text { MDP'lerin }{ }^{* *} \text { etkinliğini } \\
\text { analiz etmektir. }\end{array}$ & Anket & $\begin{array}{l}\text { MDP'ler, firmalarda ciro ve } \\
\text { istihdam düzeyini artırmıştır. }\end{array}$ \\
\hline & İçen (2012) & $\begin{array}{l}\text { İZKA'nın yerel kalkınmaya } \\
\text { katkısını tespit etmektir. }\end{array}$ & Anket & $\begin{array}{l}\text { IZKA, MDP ile kırsal kalkınmaya } \\
\text { katkıda bulunmuştur. }\end{array}$ \\
\hline & $\begin{array}{l}\text { Ersayin } \\
(2012) \\
\end{array}$ & $\begin{array}{l}\text { MDP'lerin katkısını ortaya } \\
\text { koymaktır. }\end{array}$ & Anket & $\begin{array}{l}\text { MDP'lerin \% 50'sinin, yerel } \\
\text { kalkınmaya etkisi yoktur. }\end{array}$ \\
\hline & $\begin{array}{c}\text { Günaydın } \\
(2013 b)\end{array}$ & $\begin{array}{l}\text { MDP'lerin kalkınmaya } \\
\text { etkisini belirlemektir. }\end{array}$ & $\begin{array}{c}\text { Doküman } \\
\text { Analizi }\end{array}$ & $\begin{array}{l}\text { MDP'ler, İzmir'de eğitim ve } \\
\text { istihdam düzeyini artırmıştır. }\end{array}$ \\
\hline \multirow{6}{*}{ 离 } & $\begin{array}{c}\text { Şahin vd. } \\
(2012)\end{array}$ & $\begin{array}{l}\text { SD'nin ve İZKA'nin } \\
\text { faaliyetlerini incelemektir. }\end{array}$ & $\begin{array}{c}\text { Doküman } \\
\text { Analizi } \\
\end{array}$ & $\begin{array}{l}\text { İZKA, kalkınma ve planlama } \\
\text { alanlarında gelişme sağlamıştır. }\end{array}$ \\
\hline & Çelik (2015) & $\begin{array}{l}\text { İZKA'nın yenilikçilik } \\
\text { faaliyetlerini incelemektir. }\end{array}$ & $\begin{array}{l}\text { Anket, } \\
\text { Mülakat }\end{array}$ & $\begin{array}{l}\text { İZKA, yenilikçilik faaliyetlerinde } \\
\text { bulunmuştur. }\end{array}$ \\
\hline & Çelik (2016) & $\begin{array}{l}\text { Kalkınma Kurulu'nun (KK) } \\
\text { gündem belirleme } \\
\text { faaliyetlerini incelemektir. }\end{array}$ & $\begin{array}{l}\text { Doküman } \\
\text { Analizi }\end{array}$ & $\begin{array}{l}\text { KK, İzmir'in kalkınmasına yönelik } \\
\text { gündemler belirlemiştir. }\end{array}$ \\
\hline & Çelik (2017a) & $\begin{array}{l}\text { KK'nın etkinliğini artırma } \\
\text { girişimlerini ele almaktır. }\end{array}$ & $\begin{array}{l}\text { Doküman } \\
\text { Analizi }\end{array}$ & $\begin{array}{l}\text { KK, İZKA'yı ve BKA Yasası'nı } \\
\text { sorgulamış ve öneriler getirmiştir. }\end{array}$ \\
\hline & Çelik (2017b) & $\begin{array}{l}\text { IZKA'nın İzmir'in sosyal } \\
\text { kalkınmasına katkısını } \\
\text { belirlemektir. }\end{array}$ & $\begin{array}{l}\text { Doküman } \\
\text { Analizi }\end{array}$ & $\begin{array}{l}\text { İZKA, İzmir'in sosyal } \\
\text { kalkınmasına eğitim ve istihdam } \\
\text { bakımından katkıda bulunmuştur. }\end{array}$ \\
\hline & Çelik (2018a) & $\begin{array}{l}\text { KK'yı yönetişim yaklaşımı } \\
\text { temelinde incelemektir. }\end{array}$ & $\begin{array}{l}\text { Doküman } \\
\text { Analizi }\end{array}$ & $\begin{array}{l}\text { Yönetişim yaklaşımı, KK } \\
\text { üyelerinin toplantılara katılımı } \\
\text { bakımından kısmen; kamu, özel } \\
\text { ve sivil kesimlere göre dağılımı ile } \\
\text { de tam uygulanmıştır. }\end{array}$ \\
\hline
\end{tabular}

*: Kimi çalışmalarda yöntem belirtilmemiş olup; bu, yazar tarafından belirlenmiştir.

**: MDP: Mali Destek Programı

Kaynak: Yazar tarafından geliştirilmiştir.

Tablo 1'e göre Aydoğdu (2010), Akpınar (2010), Burak (2011) ve Eldeniz (2011), IZKA'nın planlama faaliyetlerini yerel aktörlerin katılımı ile yürüttüğünü tespit etmişler. Özdemir ve İneler (2009), Haşar ve İneler (2011) ile Günaydın (2013a), IZKA'nın kümelenme faaliyetlerinin BKA'lara örnek olabileceğini vurgulamışlar. 
İZKA (2011), İçen (2012), Ersayın (2012) ve Günaydın (2013b), İZKA'nın MDP’lerle desteklediği projeler aracılığıyla İzmir'in kalkınmasına katkısını belirlemişler.

Şahin vd. (2012), İZKA'nın da SD gibi kalkınma ve planlama alanında gelişme sağladığını tespit etmişler. Çelik (2015), Avrupa (ERVET ve SD) ve Türkiye (İZKA ve ÇKA) örneğinde BKA'ların yenilikçilik faaliyetlerini incelemiştir. Çelik (2016), IZZKA KK'nın İzmir'in kalkınmasına yönelik gündem belirleme faaliyetlerini; Çelik (2017a), KK'nın etkinliğini artırma girişimlerini; Çelik (2017b), İZKA'nın sosyal kalkınmaya katkısını; Çelik (2018a) de KK'da uygulanan yönetişimi ortaya koymuştur.

\section{3. İzmir Kalkınma Ajansı - Üniversite İşbirliği}

İzmir, Türkiye' de ${ }^{21}$ ÜSİ'yi kurumsal olarak başlatan kenttir. Türkiye' de ilk defa Ege Bölgesi Sanayi Odası'nın (EBSO) öncülüğünde 1983 yılında Ege ÜniversitesiSanayi İşbirliğini Geliştirme Merkezi (ÜSİGEM) kurulmuştur. ÜSİGEM yerini, 1989 yılında EÜ'de kurulan İzmir Teknopark'a bırakmıştır. Türkiye'de ilk olan bu teknopark, İzmir'de teknolojik gelişmeye yeterince katkı sağlayamamıştır (IZZKA, 2012c: 99). Bunun üzerine İYTE'de 2003 yılında İzmir Teknoloji Geliştirme Bölgesi²2 (İZTEKGEB) kurulmuştur. İZTEKGEB'de ÜSİ ile akademisyenlere araştırmalarını ticarileştirme, öğrencilere de staj ve istihdam imkanları sağlanmıştır (İZKA, 2012a: 98).

İzmir, ÜSİ'ye üçüncü defa öncülük etmiştir. Ar-Ge faaliyetlerini artırmak için EÜ bünyesinde Bilim-Teknoloji Uygulama ve Araştırma Merkezi (EBİLTEM ${ }^{23}$, 1994) kurulmuştur. EBİLTEM, teknoloji transferini geliştirmek için AB'nin Yenilik Aktarım Merkezi Projesi'nde yer almıştır. EBİLTEM'in öncülügüünde EBSO, İzmir Atatürk Organize Sanayi Bölgesi ve KOSGEB'in işbirliğinde kurulan Ege Yenilik Aktarım Merkezi (IRC-Ege, 2004), Türkiye' de bu alandaki ilk merkezdir²4 (IZZKA,2012c: 101-102).

ÜSİ, Teknoloji Transfer Ofisi veya ÜSİ Ofisi aracılığıyla yapılmıştır. EÜ, ÜSİyi EBİLTEM; DEÜ, ÜSİ Ofisi; YÜ de Araştırma ve Geliştirme Merkezi (YAGEM) aracılığıyla yapmıştır (İZKA, 2012d: 35).

İZKA, İzmir'in ÜSİ alanındaki potansiyelini hareket geçirmek, geliştirmek ve kalkınmaya yönlendirmek üzere başta üniversiteler olmak üzere yerel aktörlerle stratejiler geliştirmiş ve projeler gerçekleştirmiştir.

\footnotetext{
${ }^{21}$ Türkiye'de ilk kez 1983 yılında ele alınan ÜSí'ye ilişkin kurumlar, 1990'larda kurulmaya başlanmıştır (IZKA, 2012a: 98). 2000'lerde kurulan Teknoloji Geliştirme Merkezleri (TEKMER) ve teknoparklar, ÜSİ'nin gelişmesini sağlamıştır. Ayrıca Türkiye Kamu-Üniversite-Sanayi İşbirliği (KÜSİ) Strateji Belgesi ve Eylem Planı (2015-2018) hazırlanmıştır. Dünyada ÜSİ konusunda 61. ve rekabet edebilirlikte 45. sırada yer alan Türkiye' de (İZKA, 2012c: 28; TSBSTB, 2015: 6) ÜKAİ'nin, ÜSİnin gelişmesine katkıda bulunması beklenir. ${ }^{22}$ TEKGEB, üniversitelerin, Ar-Ge kurumlarının ve firmaların işbirliği, bilgi üretme ve ticarileştirme faaliyetlerini destekleyen bir yapıdır. Akademisyenlerin de firma kurabildiği TEKGEB, girişimci üniversite modeline benzetilebilir.

${ }^{23}$ EBİLTEM, Türkiye Teknoloji Geliştirme Vakfı'na (TTGV) göre, Türkiye'deki ÜSİ merkezleri arasında en başarılı 6 merkezden biridir. UNESCO'un raporuna (Science Report, 2010) göre ise, Türkiye'nin en başarılı teknoloji transferi merkezidir (IZKA, 2012a: 30).

24 İkincisi ise, ODTÜ Teknokent, Ankara Sanayi Odası ve KOSGEB'in kurduğu IRC Anatolia'dır.
} 


\subsubsection{Strateji Geliştirme Alanında İşbirliği}

Strateji, uzun vadeli hedeflere ulaşmak için uygulanacak yöntemler ve faaliyetler bütünü olarak tanımlanabilir. İZA, İzmir'in yeniliklere dayalı sürdürülebilir kalkınmasını sağlamak üzere yerel aktörlerle işbirliği içinde Kümelenme Stratejisi (2008), Yenilik Stratejisi (2012), Bilgi Toplumu Stratejisi (2012) ve Girişimcilik Stratejisi (2013) geliştirmiştir (IZKA, 2008, 2012c, 2012e, 2013). Türkiye'de yerel düzeyde ilk olma özelliğine sahip bu stratejiler ile ekosistemler kurmaya çalışmıştır.

Kümelenme Stratejisi'nin amacı, İzmir'in rekabetçi sektörlerinin belirlenmesi ve desteklenmesidir. Strateji, dört aşamada geliştirilmiştir. Bunlar, kümelenme komitesi ${ }^{25}$ kurulması, istatistik ve saha analizi yapılması, bölgesel fırsatların belirlenmesi ve yol haritalarının hazırlanmasıdır. Analizler sonucunda İzmir'deki potansiyel kümeler tespit edilmiş; bunlara yönelik 3 tane öncelik ve 7 tane hedef belirlenmiştir.

Kümelenme Stratejisi'ni tamamlayıcı nitelikte IZZKA, EBİLTEM ve TUİK işbirliğinde Yenilik Stratejisi geliştirilmiştir. Strateji geliştirme sürecinde, üniversitelerin ve diğer yerel aktörlerin temsilcilerinden İzmir Yenilik Teknik Komitesi $^{26}$ ve İzmir Bölgesel Yenilik Komitesi ${ }^{27}$ oluşturulmuştur. Stratejinin amac1, İzmir'i teknoloji üreten ve ihraç eden bir düzeye yükseltmektir. Strateji geliştirme sürecinde yapılan ankette, İzmir'in yenilik ekosistemi altyapısının olduğu; ancak ArGe ve yenilik odaklı proje hazırlama, işbirliği yapma ve bunları ticarileştirme bakımından istenilen düzeyde olmadığ ${ }^{28}$ belirlenmiştir (IZKA, 2012d: 46, 50). Stratejinin 6 tane önceliklerinden ilki, "araştırma ve yenilik altyapısının güçlendirilmesi”dir. Bu öncelik kapsamında üniversitelerin, firmaların ve IZTEKGEB' in Ar-Ge altyapısının geliştirilmesi, TEKGEB'ler ve teknoparklar kurulması hedefleri öne çıkmıştır.

\footnotetext{
${ }^{25}$ Kümelenme Komitesi, başlıca şu kurumların üyelerinden oluşmuştur: Ege Üniversitesi, Dokuz Eylül Üniversitesi, İzmir Ekonomi Üniversitesi, Ege Üniversitesi - Bilim Teknoloji Uygulama ve Araştırma Merkezi (EBİLTEM), İzmir Ticaret Odası (İZTO), İzmir Büyükşehir Belediyesi, Ege Serbest Bölgesi, EGEV, Ege İhracatçı Birlikleri(EİB), Ege Serbest Bölgesi (ESBAŞ), Ege Bölgesi Sanayi Odası (EBSO), Ege Soğutma Sanayicileri ve İş Adamları Derneği (ESSİAD), İzmir Serbest Bölgesi (İZBAŞ), PETKİM, İzmir Atatürk Organize Sanayi Bölgesi, Ege Genç İş Adamları Derneği.

26 İzmir Yenilik Teknik Komitesi, şu kurumların üyelerinden oluşmuştur: Yaşar Üniversitesi, Ortadoğu Teknik Üniversitesi, Çukurova Üniversitesi, ÜSİMP, İzmir Ekonomi Üniversitesi, Anadolu Üniversitesi, TTGV, Sabancı Üniversitesi, İzmir Yüksek Teknoloji Enstitüsü, Dokuz Eylül Üniversitesi

27 İzmir Bölgesel Yenilik Komitesi, başlıca şu kurumların üyelerinden oluşmuştur: Ege Üniversitesi, İzmir Üniversitesi, İzmir Yüksek Teknoloji Enstitüsü, Yaşar Üniversitesi, Dokuz Eylül Üniversitesi, İzmir Ekonomi Üniversitesi, Gediz Üniversitesi, Sabancı Üniversitesi, İzmir Katip Çelebi Üniversitesi, EBİLTEM, Ege Sanayici ve İşadamları Derneği (ESİAD), KOSGEB, İzmir Serbest Bölgesi, Ege Bölgesi Sanayi Odası (EBSO), Ege Serbest Bölgesi, İzmir Atatürk Organize Sanayi Bölgesi.

${ }^{28}$ İzmir'in bu durumu, Avrupa Paradoksu'na benzetilebilir. Avrupa Paradoksu, AB'nin bilimsel alandaki başarısını, buluşları yeniliklere dönüştürme konusunda gösterememesidir. $A B$, bu paradoksu çözmek, verimliliği ve rekabet gücünü artırarak bilgi ekonomisine dönüşmek için teknoloji ve yenilik politikaları geliştirmiştir. İZKA'nın da benzer amaçlarla yukarıda belirtilen stratejileri geliştirdiği söylenebilir.
} 
Bilgi Toplumu Stratejisi29, İZKA ve İzmir Yüksek Teknoloji Enstitüsü (İYTE) işbirliğinde bilgi toplumu ve bilişim sektörü eksenlerinde üç aşamada hazırlanmıştır. Birinci aşamada, mevcut durum analizi, gelecek eğilimleri, fark analizi ve Delfi anketi yapılmıştır. İkinci aşamada, çalıştaylar düzenlenmiş; öncelikler ve hedefler belirlenmiştir. Üçüncü aşamada ise, strateji haritaları ve eylemler geliştirilmiştir.

Girişimcilik Stratejisi ${ }^{30}$, IZZKA ve Türkiye Ekonomi Politikaları Araştırma Vakfı (TEPAV) işbirliğinde hazırlanmıştır. Amacı, İzmir'de girişimcilik ekosistemini geliştirmektir. Hazırlık sürecinde, bazı yönlerden İzmir'e benzeyen ABD'nin kimi kentlerindeki deneyimlerden yararlanılmıştır. EÜ ve DEÜ, TEKMER ${ }^{31}$ aracılığıyla girişimcileri desteklemiştir (İZKA, 2013: 4-5, 50-51).

\subsubsection{Proje Geliştirme Alanında İşbirliği}

IZZKA, yerel aktörlerin projelerine Mali Destek Programları (MDP), Güdümlü Proje Desteği $\left(G^{32}\right)$ ve Doğrudan Finansman Desteği (DFD) aracılığıyla 2017 yılı Mayıs ayı itibariyle 229 milyon TL $^{33}$ mali destek vermiştir. Bu desteklerden üniversiteler de yararlanmıştır. Üniversite-İZKA İşbirliği, Tablo 1'deki kriterlere göre değerlendirilerek Tablo 3'de özet olarak sunulmuştur.

Tablo 3. Üniversite-İZKA İşbirliği'nin Proje Bazlı Değerlendirilmesi (2008-2015)

\begin{tabular}{|l|c|}
\hline \multicolumn{1}{|c|}{ Kriter } & Bulgu \\
\hline - Üniversite-İZKA İşbirliği yapılan üniversite sayısı & 7 \\
\hline - Üniversite-İZKA İşbirliği'nde uygulanan proje sayısı & 37 \\
\hline - Üniversite-İZKA İşbirliği'nde uygulanan projelerin bütçesi (İZKA'nın & 47 milyon TL \\
katkısı) & (41 milyon TL) \\
\hline
\end{tabular}

Kaynak: İZKA'nın MDP, GPD ve DFD değerlendire sonuçlarından yararlanılarak geliştirilmiştir.

Tablo 3'e göre İZKA, 2015 yılı itibariyle 7 tane yerel üniversite ile 37 proje kapsamında işbirliği yapmıştır. Projelerin toplam bütçesi, yaklaşık 47 milyon TL'dir. Bütçenin yaklaşık \% 87'si (41 milyon TL) İZKA tarafından karşılanmıştır. Söz konusu projelerin tamamını incelemek, çalışmanın boyutunu aşacaktır. Bu nedenle söz konusu

\footnotetext{
${ }^{29}$ Bilgi Toplumu Stratejisi geliştirilirken kurulan Danışma Komitesi'nde yer alan başlıca kurumlar şunlardır: Celal Bayar Üniversitesi, Dokuz Eylül Üniversitesi, İzmir Ekonomi Üniversitesi, Gediz Üniversitesi, Yaşar Üniversitesi, Ege Üniversitesi, İzmir Yüksek Teknoloji Enstitüsü.

${ }^{30}$ Girişimcilik Stratejisi geliştirilirken yapılan odak grup toplantılarına katılan başlıca kurumlar şunlardır: Ege Üniversitesi, Gediz Üniversitesi, İzmir Ekonomi Üniversitesi, İzmir Yüksek Teknoloji Enstitüsü, İzmir Kâtip Çelebi Üniversitesi, Ege Üniversitesi Bilim-Teknoloji Uygulama ve Araştırma Merkezi (EBİLTEM), Ege Sanayicileri ve İşadamları Derneği (ESİAD), Batı Anadolu Sanayici ve İşadamları Dernekleri Federasyonu, Ege Bölgesi Sanayi Odası, İzmir Esnaf ve Sanatkârlar Odaları Birliği, İzmir Genç Girişimciler Kurulu, Ege Genç İşadamları Derneği, İzmir Genç Müstakil Sanayici ve İşadamları Derneği.

31 TEKMER (Teknoloji Geliştirme Merkezi), KOBİlerin teknolojik yeniliklere uyum sağlamasını ve rekabet güçlerini artırmak amacıyla üniversiteler ile işbirliğinde Ar-Ge faaliyetlerinin yapıldığı bir kurumdur.

32 GPD, bölgesel kalkınmaya, rekabet gücünü artırmaya, iş ortamını, girişimcilik ve yenilikçilik kapasitesini geliştirmeye yönelik İş Geliştirme Merkezi (İŞGEM), TEKMER, teknopark gibi büyük bütçeli ve stratejik nitelikteki projelere verilen bir destektir.

${ }^{33}$ http://www.kureselanahaber.com/tekstilde-artiracak-tamamlandi/ (Erişim Tarihi: 05.04.2018).
} 
projelerden üniversitelerin dolayısıyla İzmir'in Ar-Ge ve yenilik yapma kapasitesini geliştirmeye yönelik olanlar, Tablo 4'de sunulmuştur. 
Tablo 4. Üniversite-İZKA İşbirliği'nde Gerçekleştirilen Başlıca Projeler (2008-2015*)

\begin{tabular}{|c|c|c|c|}
\hline Üniversite & Projenin Adı & Amac1 & $\begin{array}{c}\text { Bütçesi } \\
\text { (İZKA'nın Katkısı) }\end{array}$ \\
\hline \multirow{3}{*}{$\begin{array}{l}\text { Ege Üniversitesi } \\
\text { (Eய̈) }\end{array}$} & AGROLAB Projesi (2009) & $\begin{array}{l}\text { Genetiği değiştirilmiş organizmalarla (GDO) ilgili } \\
\text { analizler yapmak için laboratuvar kurmaktır. }\end{array}$ & $\begin{array}{c}400 \text { bin TL } \\
(\% 75)\end{array}$ \\
\hline & $\begin{array}{l}\text { Biyokütle Enerji Sistemleri ve Teknolojileri Merkezi } \\
\text { (BESTMER) Projesi (2014) }\end{array}$ & $\begin{array}{l}\text { Biyokütle enerji teknolojileri alanında Ar-Ge yapmak } \\
\text { üzere bir laboratuvar kurmaktır. }\end{array}$ & $\begin{array}{l}14,3 \text { milyon TL } \\
(\% 47,7)\end{array}$ \\
\hline & $\begin{array}{l}\text { Sürdürülebilir Ege - Güneş ve Biyogaz Enerji Santralı } \\
(2016)\end{array}$ & $\begin{array}{l}\text { EÜ'de biyogaz ve güneşten enerji üretmek üzere bir } \\
\text { hibrit santral kurmaktır. }\end{array}$ & $\begin{array}{l}1,25 \text { milyon TL } \\
(\% 75)\end{array}$ \\
\hline \multirow{3}{*}{$\begin{array}{c}\text { İzmir Yüksek } \\
\text { Teknoloji Enstitüsü } \\
\text { (İYTE) }\end{array}$} & $\begin{array}{l}\text { Zeytin ve Zeytinyağ İş̧leme ve Geliştirme Merkezi } \\
\text { (2009) }\end{array}$ & $\begin{array}{l}\text { Ar-Ge çalışmaları ile zeytin özsuyunu arıtacak ve } \\
\text { çevreyi kirletmeyecek bir teknolojiyi geliştirmektir. }\end{array}$ & $\begin{array}{l}583 \text { bin TL } \\
(\% 75)\end{array}$ \\
\hline & İnovasyon Merkezi (2012) & $\begin{array}{l}\text { İzmir'in Ar-Ge ve yenilik yapma kapasitesini } \\
\text { geliştirmek için bir yenilik merkezi kurmaktır. }\end{array}$ & $\begin{array}{l}7 \text { milyon TL } \\
(\% 75) \\
\end{array}$ \\
\hline & $\begin{array}{l}\text { İYTE-Yeşil Kampüs'e Doğru: İYTE Yerleşkesinde } \\
\text { Rüzgar Enerjisi Yatırım Projesi (2012) }\end{array}$ & $\begin{array}{l}\text { Rüzgar enerjisinden elektrik üretmek ve rüzgar } \\
\text { enerjisi ile ilgili araştırmaları geliştirmektir. }\end{array}$ & $\begin{array}{l}1,5 \text { milyon TL } \\
(\% 66)\end{array}$ \\
\hline $\begin{array}{c}\text { Dokuz Eylül } \\
\text { Üniversitesi (DEÜ) }\end{array}$ & $\begin{array}{l}\text { İzmir Sağlık Teknolojileri Geliştirici ve Hızlandırıcısı } \\
\text { (Bioİzmir) Projesi (2014) }\end{array}$ & $\begin{array}{l}\text { İzmir'de sağlık alanında yeni teknolojileri } \\
\text { uygulayacak bir merkez kurmaktır. }\end{array}$ & $\begin{array}{l}9,2 \text { milyon TL } \\
(6,9 \text { milyon } \mathrm{TL})\end{array}$ \\
\hline $\begin{array}{l}\text { İzmir Katip Çelebi } \\
\text { Üniversitesi (İKÇÜ) }\end{array}$ & $\begin{array}{l}\text { Fotovoltaik Rüzgar Hibrit Enerji Santralının Kurulumu } \\
\text { Projesi (2012) }\end{array}$ & $\begin{array}{l}\text { Güneş ve rüzgar enerjisi alanında teknik uzman ve } \\
\text { ara eleman ihtiyacını karşılamaktır. }\end{array}$ & $\begin{array}{l}\text { 1,1 milyon TL } \\
(838 \text { bin TL) }\end{array}$ \\
\hline \multirow{2}{*}{$\begin{array}{l}\text { Gediz Üniversitesi } \\
\qquad\left(\mathrm{GÜ}{ }^{* *}\right)\end{array}$} & Güneş ve Rüzgardan Elektrik Enerjisi Üretilmesi (2011) & $\begin{array}{l}\text { Güneş ve rüzgardan aynı anda elektrik üretmek için } \\
\text { bir santral (hibrit santral) kurmaktır. }\end{array}$ & $\begin{array}{l}2.2 \text { milyon TL } \\
(1 \text { milyon TL })\end{array}$ \\
\hline & $\begin{array}{l}500 \text { Kw Güneş-Rüzgâr Kombinasyonlu Hibrit } \\
\text { Teknolojilerle Yenilenebilir Enerji Üretimi Projesi (2012) }\end{array}$ & $\begin{array}{l}\text { Üniversite kampüsünün elektrik enerjisi ihtiyacının } \\
\text { yarısını karşılamaktır. }\end{array}$ & $\begin{array}{l}2,1 \text { milyon TL } \\
\text { (984 bin TL) }\end{array}$ \\
\hline $\begin{array}{l}\text { İzmir Ekonomi } \\
\text { Üniversitesi (İEÜ) }\end{array}$ & $\begin{array}{l}\text { İzmir Bilimsel Araştırma, Uygulama, Test ve Sistem } \\
\text { Geliştirme Laboratuvarları Projesi (TEKNOLAB İzmir) }\end{array}$ & $\begin{array}{l}\text { TEKNOLAB İzmir adlı akredite bilimsel araştırma, } \\
\text { uygulama ve test laboratuvarı kurmaktır. }\end{array}$ & 10 milyon TL \\
\hline İBB-EÜ-YÜ & İzmir Kent Koleji Projesi (2015) & $\begin{array}{l}\text { İzmir'in rekabet ve ekonomik gelişme düzeyini } \\
\text { artıracak sektörlere nitelikli işgücü sağlamaktır. }\end{array}$ & $\begin{array}{l}\text { 3,1 milyon TL } \\
(\% 75) \\
\end{array}$ \\
\hline EİB-DEÜ & $\begin{array}{l}\text { Teknik Tekstil Mükemmeliyet Merkezi (TEKSMER) } \\
\text { Projesi (2014) }\end{array}$ & $\begin{array}{l}\text { Tekstil sektörünün Ar-Ge kapasitesini artırmak ve } \\
\text { üniversite-sanayi işbirliğini geliştirmektir. }\end{array}$ & $\begin{array}{c}4,5 \text { milyon TL } \\
(\% 75)\end{array}$ \\
\hline $\begin{array}{l}\text { ESSİAD-EBSO-EÜ- } \\
\text { İYTE }\end{array}$ & $\begin{array}{l}\text { Endüstriyel Havalandırma, İklimlendirme ve Soğutma } \\
\text { Amaçlı Akredite Test ve Analiz Laboratuvarı (2015) }\end{array}$ & $\begin{array}{l}\text { İZTEKGEB Teknopark alanında Türkiye'nin ilk } \\
\text { akredite test ve analiz laboratuvarını kurmaktır. }\end{array}$ & $\begin{array}{l}\text { 4,7 milyon TL } \\
(\% 75)\end{array}$ \\
\hline
\end{tabular}

*: İZKA'nın mali destekleri, 2008 yılında başlamış ve günümüzde en son 2015 yılı Mali Destek Programı uygulanmıştır.

**: Gediz Üniversitesi'nin ismi daha sonra İzmir Bakırçay Üniversitesi (İ̈Ü) olarak değiştirilmiştir.

Kaynak: İZKA'nın 2008-2015 dönemi MDP, GPD ve DFD proje değerlendirme sonuçlarından yararlanılarak geliştirilmiştir. 
Tablo 4'e göre İZKA, İzmir'deki üniversitelerin Ar-Ge altyapısını geliştirmeye yönelik projelerine 41 milyon TL destek vermiştir. Projeler kapsamında bölgesel ve/ veya ulusal düzeyde ilk olma özelliğine sahip kimi kurumların kurulmasına katkıda bulunmuştur. Bu çerçevede AGROLAB, BESTMER, TEKNOLAB, TEKSMER, Akredite Test ve Analiz Laboratuvarı, Zeytin ve Zeytinyağı İşleme ve Geliştirme Merkezi, İnovasyon Merkezi, Bioİzmir gibi Ar-Ge kurumlarının yanısıra rüzgar, güneş gibi yenilenebilir enerji kaynaklarından elektrik üretmeye yönelik santrallar kurulmuştur.

\section{Sonuç}

$\mathrm{Bu}$ çalışmada Üniversite-BKA İşbirliği (ÜKAİ) kavramı, İzmir Kalkınma Ajansı'nın (IZZKA) ve üniversitelerin işbirliği örneğinde Tablo 1'deki kriterlere göre analiz edilmiştir. IZZKA'nın amac1, İzmir'in yönetişim temelinde sürdürülebilir kalkınmasını sağlamaktır. Bu amaçla ve Yenilikçi İzmir vizyonu ile üniversitelerle işbirliği içinde kentin Ar-Ge ve yenilik yapma kapasitesini geliştirmiştir.

İzmir'de Üçlü Sarmal Modeli'nde belli ölçüde "kamu"nun rolünü üstlenen İZKA, bir BKA ve BYS'nin “aracı kurum"u (bkz. Şema 1) olarak yeniliklere yönelik "arz tarafı" ile "talep tarafı"nın işbirliği yapmasını sağlamıştır. İzmir'in Ar-Ge ve yenilik yapma kapasitesini artırmak ve bilgi toplumuna dönüşmesini sağlamak üzere başta üniversiteler, yerel aktörler ile kümelenme, yenilik, girişimcilik ve bilgi toplumu stratejilerini geliştirmiş; desteklediği projelerle Ar-Ge kurumlarının kurulmasını sağlamıştır (bkz. Tablo 3-4). İZKA'nın mali destekleri ile gerçekleştirilen projelerin, İzmir'in küresel rekabet gücünü artıracağı ve üniversitelerin 2. Kuşak'tan 3. Kuşağa ve II. Akademik Devrim'den III. Akademik Devrim'e geçmesine katkıda bulunacağı söylenebilir.

Üniversite-İZKA İşbirliğ̣i, yerel kalkınmada aktörler arasında işbirliğini geliştirmek ve sinerji yaratmak bakımından örnek bir deneyimdir. 16 yıllık deneyimi ile İZKA'nın yerel üniversitelerle işbirliği faaliyetlerinin, İngiltere, İrlanda, Avusturya örneklerindeki NWDA, SD, SFG ajansları ile uyumlu olduğu gözlenmiştir. İZKA'nın, kurulmasına öncülük ettiği BESTMER, İnovasyon Merkezi, Bioİzmir, TEKNOLAB, TEKSMER gibi Ar-Ge kurumlarından hareketle İrlanda'nın Shannon Bölgesi'nde geliştirilen SD-UL Modeli'ne benzer bir"model” geliştirmesi beklenebilir.

ÜKAİ konusunda sorgulanması gereken hususlardan biri, etkinliktir. Bu bakımdan ÜKAİ için tahsis edilen kaynakların, yerel kalkınmaya üretim, istihdam, ihracat, Ar-Ge, yenilik gibi yönlerden katkısını belirlemek için "etki analizi"nin yapılması önerilebilir.

Yerel kalkınmanın başlıca iki aktörü olan BKA'nın ve üniversitelerin işbirliğinde (ÜKAİ) yaratılan sinerjinin ve kurulan kurumların Türkiye (İzmir) örneğinde incelendiği bu araştırmanın, literatüre katkıda bulunması beklenmektedir. 


\section{Kaynakça}

Akpınar, R. (2010). Türkiye'de Kalkınma Ajanslarınca Hazırlanan Bölge Planlarına Dair Bir Kritik: İZKA'nın İzmir Bölge Planı (2010-2013) Örneği, Dokuz Eylül Üniversitesi Sosyal Bilimler Enstitüsü Dergisi, 12 (4): 7-18.

Albulescu, I. and Albulescu, M. (2014). The University in The Community. The University's Contribution to Local and Regional Development by Providing Educational Services for Adults, Procedia-Social and Behavioral Sciences, 142 (14): 5-11.

Aydoğdu, Ç. (2010). Kalkınma Ajansları ve Toplumsal Sermaye İlişkilerinde Stratejik Yaklaşım. (Basılmamış Yüksek Lisans Tezi). İzmir: Dokuz Eylül Üniversitesi Sosyal Bilimler Enstitüsü.

Asheim, B. T. and Isaksen, A. (1996). Location, Agglomeration and Innovation: Towards Regional Innovation Systems in Norway? 52 p.

Bellini, N. (2000). Real Services': A Re-appraisal, European Planning Studies, 8 (6): 711-728.

Boucher, G. W. (2000). Unireg Regional Case Study Report The Shannon Region. 74 p.

Boucher, G., Conway, C. and Meer, E. Van Der. (2003). Tiers of Engagement by Universities in Their Region's Development, Regional Studies, (37) 9: 887-897.

Bramwell, A. and Wolfe, D. A. (2005). Universities and Regional Economic Development: The Entrepreneurial University of Waterloo. Annual Conference The University of Western Ontario London, Ontario, $43 \mathrm{p}$.

Camagni, R. and Capello, R. (2012). Regional Innovation Patterns and the EU Regional Policy Reform: Towards Smart Innovation Policies, 52. ERSA Conference in Bratislava, 25 p.

CEC (Commission Of The European Communities). (2001). European Governance: A White Paper, COM (2001) 428 final, Brussels, 35 p.

Charles, D. (2006). Universities as Key Knowledge Infrastructures in Regional Innovation Systems, European Journal of Social Science Research, 19 (1): 117-130.

Clara, M. (2000). Real Service Centres in Italian Industrial Districts Lessons Learned From A Comparative Analysis. UNIDO, 23 p.

Clark, B. R. (1998). The Entrepreneurial University: Demand and Response, Tertiary Education and Management, 4 (1): 5-16.

Cooke, P. (2004), The Role of Research in Regional Innovation Systems: New Models Meeting Knowledge Economy Demands, International Journal of Technology Management, 28: 507533.

Cooke, P. and Memedovic, O. (2003). Strategies for Regional Innovation Systems: Learning Transfer and Applications, UNIDO World Industrial Development Report, 25 p.

Çelik, F. (2015). Bölgesel Kalkınma Ajanslarının Yeniliklere Katkıları: Teori, Deneyimler ve Türkiye Uygulamalarının Değerlendirilmesi. (Basılmamış Doktora Tezi). Kayseri: Erciyes Üniversitesi Sosyal Bilimler Enstitüsü.

Çelik, F. (2016). İzmir Kalkınma Ajansı (İZKA) Örneğinde Kalkınma Kurulu'nun Gündem Belirleme Faaliyetlerinin Değerlendirilmesi, Nevşehir Hacı Bektaş Veli Üniversitesi Sosyal Bilimler Enstitüsü Dergisi, 6 (2): 45-67. 
Çelik, F. (2017a). İzmir Kalkınma Ajansı (İZKA) Kalkınma Kurulu'nun Etkinliğini Artırma Girişimleri, Süleyman Demirel Üniversitesi Sosyal Bilimler Enstitüsü Dergisi, 27 (2): 55-80.

Çelik, F. (2017b). Bölgesel Kalkınma Ajansları'nın Sosyal Kalkınmaya Katkısı: İzmir Kalkınma Ajansı (IZKA) Örneği, Mehmet Akif Ersoy Üniversitesi Sosyal Bilimler Enstitüsü Dergisi, 9 (19): 148-170.

Çelik, F. (2017c). Bölgesel Kalkınma Ajansı (BKA) Deneyimlerinin Karşılaştırmalı Analizi: İngiltere ve Türkiye Örnekleri, Afyon Kocatepe Üniversitesi Sosyal Bilimler Dergisi, 19 (2): 145-171.

Çelik, F. (2018a). İzmir Kalkınma Ajansı Örneğinde Kalkınma Kurulu'nun Yönetişim Yaklaşımı ile Analizi, Karabük Üniversitesi Sosyal Bilimler Enstitüsü Dergisi, 8 (2): 364-386.

Çelik, F. (2018b). Shannon Kalkınma Ajansı'nın (İrlanda) Yenilikçilik Faaliyetleri, Ankara Üniversitesi Sosyal Bilimler Dergisi, 9 (2): 14-36.

Çelik, F. ve Yıldız, R. (2015). Yerel Kalkınma Sorunu ve Bunun Çözümünde Üniversitelerin Rolü: Shannon Kalkınma Ajansı (SD) ve Limerick Üniversitesi (UL) Örneği. 3. Uluslararası Bölgesel Kalkınma Konferansı, Bingöl, 532-548.

Dineen, D. A. (1995). The Role of A University in Regional Economic Development: A Case Study of The University of Limerick, Industry and Higher Education, 9: 140-148.

Dulupçu, M. A. (2006). Bölgesel Politikalar Kopyalanabilir mi? Bölgeselleşme Karşısında Yeni Bölgeselcilik, Bölgesel Kalkınma ve Yönetişim Sempozyumu içinde, Ankara, 233-255.

Dura, C. (1994). Üniversite-Sanayi İşbirliği Üzerine Bir Deneme, Ankara Üniversitesi Siyasal Bilgiler Fakültesi Dergisi, 49 (3): 101-117.

Eldeniz, F. (2011). The Assessment Of Institutional Performance in Izmir Development Agency. (Basılmamış Yüksek Lisans Tezi). Ankara: Orta Doğu Teknik Üniversitesi Sosyal Bilimler Enstitüsü.

Eraydın, A. (2007). Politikalardan Süreç Tasarımına: Yeni Bölgesel Politikalar ve Yönetişim Modelleri, 2. Bölgesel Kalkınma ve Yönetişim Sem., İzmir, 5-23.

Eren, E. ve Koşan, N. İ. (2012). The Importance of the Cooperation of Regional Development Agencies with Universities Founded in the Provinces in Terms of Entrepreneurship and Innovation Projects, Social and Behavioral Sciences, 41: 363-366.

Ersayın, Z. (2012). Kamu Müdahalelerinde Katkısallı̆̆n Değerlendirilmesi: Çukurova ve İzmir Kalkınma Ajansları KOBİ Destekleri Örneği. (Basılmış Uzmanlık Tezi). Ankara: Devlet Planlama Teşkilatı.

Etzkowitz, H. (2003). Research Groups As 'Quasi-Firms': The Invention of The Entrepreneurial University, Research Policy, 32: 109-121.

Etzkowitz, H. and Leydesdorff, L. (1995). The Triple Helix-University-Industry-Government Relations: A Laboratory for Knowledge-Based Economic Development, EASST Review, 14: 14-19.

Etzkowitz, H. and Leydesdorff, L. (2000). The Dynamics of Innovation: From National Systems and 'Mode 2' to a Triple Helix of University-Industry-Government Relations, Research Policy, 29 (2): 109-123. 
Etzkowitz, H. and Viale, R. (2010). Polyvalent Knowledge and The Entrepreneurial University: A Third Academic Revolution? Critical Sociology, 36 (4): 595-609.

EURADA. (1999). Creation, Development and Management of RDAs. Does it have to be so difficult? $169 \mathrm{p}$.

Goddard, J. B. and Chatterton, P. (1999). Regional Development Agencies and the Knowledge Economy: Harnessing the Potential of Universities, Environment and Planning C: Government and Policy, 17: 685-699.

Günaydın, D. (2013a). Bölgesel Kalkınma Sürecinde Kümelenmeler: TR31 İzmir Bölgesi Örneği, International Anatolia Academic Online Journal, 1 (2): 11-47.

Günaydın, D. (2013b). Türkiye'de Bölgeler Arası Gelişmişlik Farkların Giderilmesinde Kalkınma Ajanslarının Yeri: İZKA Mali Destek Programları Örneği, Dokuz Eylül Üniversitesi Sosyal Bilimler Enstitüsü Dergisi, 15 (1): 73-101.

Halkier, H. (2000). Regional Policy An Inter-Organisational Approach, Regional and Industrial Policy Research Paper Number 37, European Policies Research Centre University of Strathclyde, UK, $53 \mathrm{p}$.

Halkier, H. (2006). Bölgesel Kalkınma Ajansları ve Çok Düzlemli Yönetişim: Avrupa Perspektifi, 1. Bölgesel Kalkınma ve Yönetişim Sempozyumu, Ankara, 17-28.

Halkier, H. (2010). Regional Policiy in European Regions: A Survey of Regional Development Agency Policies and Their Knowledge Implications, $50 \mathrm{p}$.

Halkier, H. (2011). Regional Development Agencies: European Trends and Experiences, in C. C. Aktan (Ed.), The Proceedings of 1st International Conference on Regional Development. Malatya, Turkey: Firat Development Agency, 1-10.

Harloe, M. and Perry, B. (2004). Universities, Localities and Regional Development: The Emergence of the 'Mode 2' University? International Journal of Urban and Regional Research, 28 (1): 212-23.

Haşar, E. Ç. ve İneler, F. M. (2011). İzmir Kümelenme Stratejisi Deneyimi ve Kümelenmenin Yönetimi, 5. Bölgesel Kalkınma ve Yönetişim Sempozyumu, Ankara, 253-272.

Helvacıoğlu K., A. ve Tektaş, A. (2010). Bölgesel Kalkınma Ajansları: Etkin Fon Kullanımı ve Çok Düzeyli Yönetişime Geçiş, Akgül, B. ve Uzay, N. (Ed.), Türkiye'de Bölgesel Kalkınmanın Yeni Örgütleri, Kalkınma Ajansları, Bursa: Ekin Yay., 535-552.

Holzschlag, G., Kerschbaumer, M., Gruber, M. and Pohn-Weidinger, S. (2009). Cluster and Innovation Promotion in Styria, Asia Pacific Tech Monitor, 26 (4): 11-21.

İçen, A. (2012). Türkiye'deki Bölgesel Kalkınma Ajanslarının Kırsal Kalkınmadaki Rolü: İzmir Kalkınma Ajansı Örneği. (Basılmamış Yüksek Lisans Tezi). Yalova: Yalova Üniversitesi Sosyal Bilimler Enstitüsü.

IZZKA. (2008). İzmir Kümelenme Stratejisi 2013-2018, 36 s.

İZKA. (2010). İzmir Bölge Planı 2010-2013, $161 \mathrm{~s}$.

İZKA. (2011). İZKA Etki Analizi Araştırması, $117 \mathrm{~s}$.

İZKA. (2012a). İzmir Bölgesel Ar-Ge ve Yenilik Kapasitesi Analizi, 123 s.

İZA. (2012b). 2011 Faaliyet Raporu, 114 s. 
İZKA. (2012c). İzmir Bölgesel Yenilik Stratejisi, $110 \mathrm{s.}$

İZKA. (2012d). İzmir'de Ar-Ge ve Yenilik Ekosisteminin Mevcut Durumu, $52 \mathrm{~s}$.

İZKA. (2012e). İzmir Bilgi Toplumu Temelli Kalkınma Stratejisi, 137.

İZKA. (2013). İzmir Girişimcilik Ekosisteminin Geliştirilmesi Projesi, 111 s.

KB (Kalkınma Bakanlığı). (2012). Kalkınma Ajansları Genel Faaliyet Raporu 2012, 196 s.

KB. (2013). Kalkınma Ajansları 2013 Yılı Genel Faaliyet Raporu, 295 s.

Landabaso, M. and Reid, A. (1999). Developing Regional Innovation Strategies: The European Commission as Animateur, in Regional Innovation Strategies. Morgan, K. and Nauwelaers, C. (Ed.) The Stationery Office. Regional Studies Association, 18-38.

Morris, M. (2010). Multi-Sectoral Collaboration and Economic Development: Lessons from England's Regional Development Agencies, 51 p.

Müftüoğlu, B. G. (2012). Türkiye'de Yeni Emek Denetim ve Kontrol Alanı: Kalkınma Ajansları, Çalışma ve Toplum, 33 (2): 95-116.

NWDA. (2011a). Business, People and Places (Learning from the NWDA's Experience), 45 p.

NWDA. (2011b). Annual Review 2006-2007, 17 p.

OECD. Shannon Development: Sample Case Studies (50 Years '1959-2009' of Commitment to the Shannon Region), $31 \mathrm{p}$.

Parker, R. (2008). Governance and The Entrepreneurial Economy: A Comparative Analysis of Three Regions, Entrepreneurship Theory and Practice, 32 (5): 833-854.

Popescu, A. I. (2011). The University as a Regional Development Catalyst: Frameworks to Assess the Contribution of Higher Education to Regional Development. Academy of Economic Studies, Bucharest, Romania, $11 \mathrm{p}$.

Porter, M. (2007). Colleges and Universities and Regional Economic Development: A Strategic Perspective, Forum for the Future of Higher Education, Cambridge, 41-44.

Roberts, P. W., and Lloyd, M. G. (1999). Institutional Aspects of Regional Planning, Management, and Development: Models and Lessons from the English Experience, Environment and Planning B: Planning and Design, 26 (4): 517-531.

Roper, S., Hewitt-Dundas, N. and Savage, M. (2002). Benchmarking Innovation Performance in Ireland's Three NUTS 2 Regions. $44 \mathrm{p}$.

Salvador, E. (2008). Regional Innovation Policies in The United Kingdom: The New IndustryHEIS Relationship and The Role of Science Parks, Revista Galega de Economía, 17 (1): 1-23.

SD (Shannon Development). (2005). Annual Report 2005, 103 p.

Sungur, O. ve Keskin, H. (2011). Yenilikte Sistem Yaklaşımı ve Bölgesel Yenilik Sistemleri: Kavramlar, Kuramlar, Politikalar, I. Uluslararası Bölgesel Kalkınma Konferansı içinde, Malatya, 161-168.

Şahin, A., Sevinç, İ. ve Taşpınar, Y. (2012). Bölgesel Kalkınmada Ajans Modeli: Shannon ve İzmir Kalkınma Ajansları, 7. Kamu Yönetimi Sempozyumu Bildirileri, Manisa, 33 p.

TCBSTB (Türkiye Cumhuriyeti Bilim, Sanayi ve Teknoloji Bakanlığı). (2015). Türkiye KamuÜniversite-Sanayi İşbirliği (KÜSI) Stratejisi ve Eylem Planı (2015-2018). 
Tödtling, F. (2001). Industrial Clusters and Cluster Policies in Austrian Regions, Cluster Policies-Cluster Development? Ed.: Åge Mariussen. Stockholm, Nordregio Report 2001:2, 59-78.

Tödtling, F., Kaufmann, A. and Sedlacek, S. (1998). The State of a Regional Innovation System in Styria: Conclusions and Policy Proposals, $57 \mathrm{p}$.

Tödtling, F. and Trippl M. (2005). One Size Fits All? Towards a Differentiated Regional Innovation Policy Approach, Research Policy, 34: 1203-1219.

Trippl, M., Sinozic, T. and Smith, H. L. (2012). The "Third Mission" of Universities and The Region: Comparing the UK, Sweden and Austria, 52nd Congress of the European Regional Science Association, Bratislava, Slovakia, 24 p.

Trippl, M., Sinozic, T. and Smith, H. L. (2014). The Role of Universities in Regional Development: Conceptual Models and Policy Institutions in The UK, Sweden and Austria, 33 p.

TSB (Technology Strategy Board). (2010). Accelerating Business Innovation Across the UK, 43 p.

Uyarra, E. (2008). What is Evolutionary About 'Regional Systems of Innovation'? Implications for Regional Policy, Manchester Business School Working Paper, 23 p.

Uyarra, E. and Haarich, S. N. (2002). Evaluation, Foresight and Participation as New Elements For Regional Innovation Policy Practice: Lessons From The Regional Innovation Strategies (RIS). ERSA Conference, Dortmund, $20 \mathrm{p}$.

Wissema, J. G. (2009). Towards the Third Generation University: Managing the University in Transition, Edward Elgar Publishing, $272 \mathrm{p}$.

Wolfe, D. A. (2005). The Role of Universities in Regional Development and Cluster Formation. in G. A. Jones, P. L. McCarney \& M. L. Skolnik (eds.), Creating Knowledge, Strengthening Nations: The Changing Role of Higher Education, University of Toronto Press, 167-94.

Yıldırım, A. ve Şimşek, H. (2013). Sosyal Bilimlerde Nitel Araştırma Yöntemleri. Ankara: Seçkin Yayıncilık, $448 \mathrm{~s}$.

Youtie, J. and Shapira, P. (2008). Building An Innovation Hub: A Case Study of The Transformation of University Roles in Regional Technological and Economic Development, Research Policy, 37: 1188-1204. 